\title{
Hand hygiene among healthcare workers - theoretical knowledge and microbiological effectiveness of hand disinfection in practice
}

\section{Higiena rąk wśród pracowników ochrony zdrowia - wiedza teoretyczna a skuteczność mikrobiologiczna dezynfekcji rąk w praktyce}

\author{
'Department of Hygiene, Medical University of Wroclaw, Poland \\ Head of the Department: Prof. Krystyna Pawlas PhD \\ ${ }^{2}$ Department of Pediatric Surgery, Marciniak Hospital, Wroclaw, Poland \\ Head of the Department: Prof. Jan Godziński MD, PhD
}

Justyna Piwowarczyk ${ }^{1}$, Anna M. Kawalec ${ }^{1}$, Agata Kawalec ${ }^{1,2}$, Krystyna Pawlas ${ }^{1}$

Key words: knowledge, healthcare workers, hand hygiene, medical staff, hand disinfection.

Słowa kluczowe: wiedza, pracownicy ochrony zdrowia, higiena rąk, personel medyczny, dezynfekcja rąk.

\begin{abstract}
Introduction: Hand hygiene is very often omitted or improperly performed by healthcare workers. Knowledge of hygienic procedures and guidelines may play a pivotal role in the effectiveness of healthcare workers hand disinfection.

Aim of the research: The assessment of potential correlation between theoretical knowledge of guidelines to hand hygiene and the frequency of theoretical and practical training in hand hygiene on the microbiological effectiveness of hand disinfection.

Material and methods: The study was conducted among 200 healthcare workers. For the assessment of the healthcare workers' knowledge of hand hygiene a self-designed questionnaire was used. The microbiological effectiveness of hand hygiene was performed by collecting pre- and post-disinfected handprints. We assumed that a decrease in bacteria levels on the hands after disinfection indicates the effectiveness of hand hygiene.

Results: The analysis of microbiological tests demonstrated that the levels of bacteria on healthcare workers' hands differ according to theoretical knowledge of guidelines for hand hygiene. The group with better results in the knowledge test had a lower number of microorganisms on their hands after hand disinfection. Participants had many problems with identification of situations in which hand disinfection is obligatory. Among wrong answers the most common were: belief that gloves can replace hand disinfection (31\%), and lack of knowledge that hand rub must be performed before contact with the patient (30\%). More than one theoretical training per year was associated with better hand disinfection efficiency.

Conclusions: Theoretical knowledge of hand hygiene affects compliance with hand hygiene recommendations and results in better microbiological effectiveness of performed procedures. The fact that HCWs are not aware in which moments they should disinfect their hands highlight the need for designing and implementation of adequate multi-modal strategies for improvement of hand hygiene.
\end{abstract}

\section{Streszczenie}

Wprowadzenie: Higiena rąk jest bardzo często pomijana lub niewłaściwie wykonywana przez pracowników ochrony zdrowia. Znajomość procedur higienicznych i zaleceń może odgrywać znaczącą rolę w skuteczności dezynfekcji rąk wykonywanej przez personel medyczny.

Cel pracy: Ocena potencjalnego związku między teoretyczną znajomością zaleceń dotyczących higieny rąk oraz częstością szkoleń z tego zakresu a skutecznością mikrobiologiczną dezynfekcji rąk.

Materiał i metody: Badanie zostało przeprowadzone wśród 200 pracowników ochrony zdrowia. Do oceny wiedzy teoretycznej personelu użyto autorskiego kwestionariusza. Mikrobiologiczna skuteczność higieny rąk została oceniona poprzez zebranie od uczestników odcisków rąk przed dezynfekcją i po dezynfekcji. Za wskaźnik skuteczności higieny rąk przyjęto zmniejszenie liczby bakterii na rękach po dezynfekcji.

Wyniki: Analiza testów mikrobiologicznych wykazała, że liczba bakterii na rękach personelu medycznego różni się w zależności od posiadanej wiedzy teoretycznej z zakresu higieny rąk. W grupie, która osiągnęła wyższy wynik z testu, liczba bakterii na rękach po dezynfekcji była mniejsza niż w grupie z niższym wynikiem. Uczestnicy mieli problemy ze wskazaniem sytuacji, w których dezynfekcja rąk jest niezbędna. Najczęstszymi spośród błędnych odpowiedzi były: przekonanie, że jednorazowe rękawice mogą zastąpić dezynfekcję rąk (31\%), brak wiedzy o konieczności dezynfekcji rąk przed kontaktem z pacjentem (30\%). Więcej niż jedno szkolenie teoretyczne w ciągu roku wiązało się z lepszą skutecznością dezynfekcji rąk. 
Wnioski: Wiedza teoretyczna dotycząca higieny rąk wpływa na przestrzeganie zaleceń z tego zakresu oraz na większą skuteczność mikrobiologiczną wykonywanych procedur. Fakt, że personel medyczny nie jest świadomy momentów, w których powinien dezynfekować ręce, powoduje, że konieczne jest zaprojektowanie i wdrożenie odpowiednich wielokierunkowych działań zwiększających przestrzeganie higieny rąk.

\section{Introduction}

Although the history of hand hygiene is very long, and Semmelweis observations date back to 1847, the problem of accurate hand disinfection is still up to date. Modern medicine faces the problem of healthcare-associated infections with all its consequences, such as increasing mortality rate or spreading antimicrobial resistance [1-3]. Hand hygiene with the use of alcohol-based hand disinfectant is a simple and short procedure; however, this basic means of prevention is very often omitted or improperly performed by healthcare workers (HCWs), with mean baseline rates ranging from 5\% to $89 \%$ and an overall average of $38.7 \%[1,3,4]$, higher among nurses $(75-39 \%)$ than doctors $(47-15 \%)[5,6]$, and dependent on the observed situation, e.g. $40-85 \%$ of doctors and nursing staff perform hand hygiene before touching a patient and $51-89 \%$ after touching a patient, with disinfection rates up to $100 \%$ after body fluid risk [7]. Potential reasons of poor compliance to hand hygiene include: lack of knowledge of guidelines, failure to identify which situations require hand hygiene, lack of role models from colleagues and superiors, work overload, lack of time, lack of appropriate infrastructure, and scepticism about the value of hand hygiene $[1-4,7,8]$. Therefore, knowledge of hygienic procedures and guidelines among HCWs may play a pivotal role in the effectiveness of hand disinfection; in particular, an insufficient theoretical base can contribute to improper hand hygiene. The World Health Organisation (WHO) underlines the need for comprehensive and constant training and education on the importance of hand hygiene among HCWs [1, 2].

\section{Aim of the research}

The assessment of potential correlation between theoretical knowledge of guidelines on hand hygiene among HCWs and its microbiological effectiveness in practice. The assessment of awareness of the constant need for education in hand hygiene among HCWs. Description of the impact of theoretical and practical training in hand hygiene and their frequency on hand disinfection effectiveness.

\section{Material and methods}

The study was approved by the Bioethics Committee at Wroclaw Medical University (consent no. $\mathrm{KB}$ - 475/2013) and was conducted from October 2013 to November 2013. According to conditions required by the Scientific Committee and due to financial limitations, the study group consisted of 200 healthcare workers from seven hospitals located in the southwest region of Poland. The volunteer participants were practicing doctors and nurses who agreed to participate in the study.

We assumed that a decrease in the number of colony-forming units (CFUs) after hand disinfection is an indicator of the microbiological effectiveness of the performed procedure. In order to quantify the bacterial level on HCW's hands the palm imprint method was used before and after hand disinfection for each participant. Microbial contamination of the hands was evaluated with the use of TSA with LECITHIN \& TWEEN 80 COUNT - TACT according to the manufacturer's instructions; the surface of all plates was $25 \mathrm{~cm}^{2}$. The subjects placed the palm of their right hand on the surface of individual plates for $10 \mathrm{~s}$. All the samples were transported to the laboratory within $2 \mathrm{~h}$ and incubated at $35^{\circ} \mathrm{C}$ for $48 \mathrm{~h}$. After incubation the colonies were counted and the results were expressed as colony-forming units per $100 \mathrm{~cm}^{2}\left(\mathrm{CFU} / 100 \mathrm{~cm}^{2}\right)$.

The assessment of HCWs' knowledge in the field of hand hygiene recommendations was performed with the use of a self-designed questionnaire. There were 12 questions, including multiple-choice questions, which assessed the knowledge WHO Guidelines on Hand Hygiene in Health Care. Subjects were asked about procedures of hand washing and hand disinfection, in which situations they should be performed, and technical aspects of the procedure (i.e. duration of hand disinfection and volume of hand-disinfectant). For each correct answer one to two points in singlechoice and one point in multiple-choice questions was added, with a maximum of 29 points if all the correct answers were chosen. For the statistical analysis participants were divided into two groups according to the results: good or very good knowledge with more than $75 \%$ of correct answers, or insufficient knowledge if $75 \%$ or fewer of the answers were correct.

\section{Statistical analysis}

Data were analysed using MS Excel and Statistica 12 software. ANOVA test was used for testing the equality of mean CFU on HCW's hands between groups divided due to the results of knowledge assessment and declared frequency of theoretical training in hand hygiene. Statistical significance was set at $p<0.05$.

\section{Results}

Among participants there were 168 (84\%) women and $32(16 \%)$ men, and according to the type of medical profession: 141 (69\%) nurses and 62 (31\%) medical 


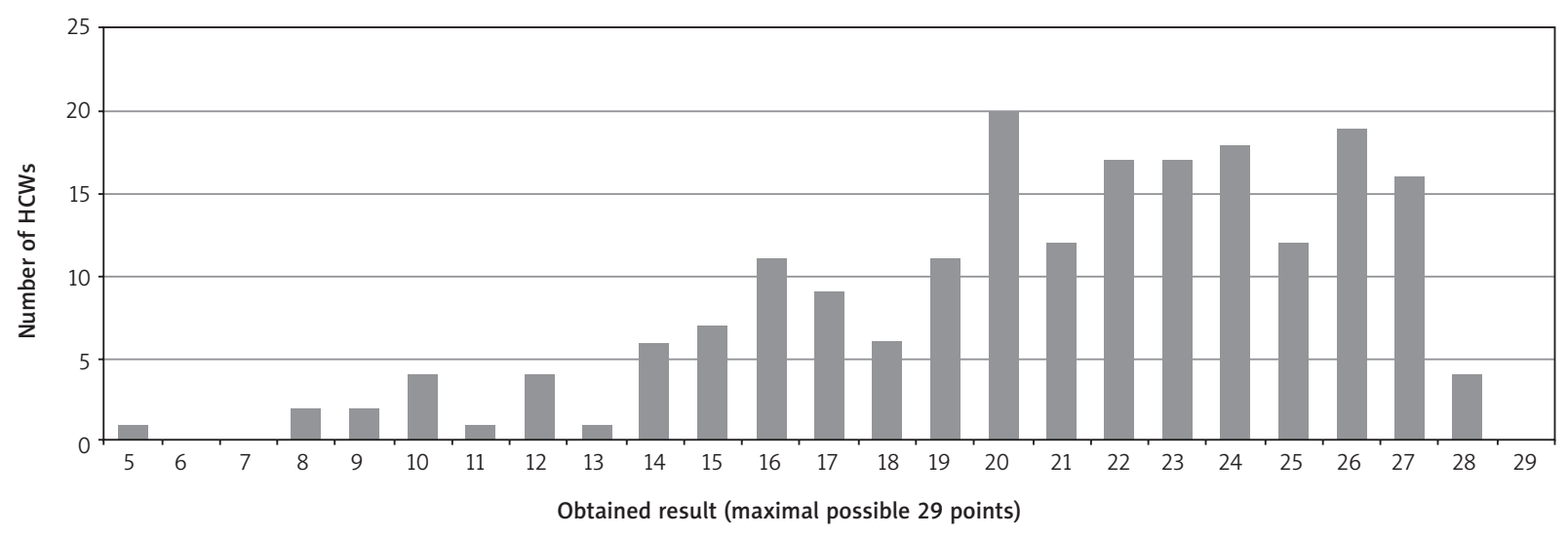

Figure 1. Results of knowledge questionnaire. Maximal possible score to obtain was 29. Number of healthcare workers (HCWs) - 200

doctors. The age of the respondents varied from 23 to 66 years.

\section{The knowledge of hand hygiene recommendations and declared need of training}

The maximum score in the knowledge test, i.e. 29 points, was achieved only by four healthcare workers. The mean score from the questionnaire was higher among nurses, and was 21.21 points, while among doctors it was 19.92 points. The most common among the wrong answers were: conviction about the necessity of hand wash before each contact with the patient (118; 59\%), belief that gloves can replace hand disinfection $(62 ; 31 \%)$, or that hand disinfection is not required if glove changing is performed (164; 82\%). In addition, participants had many problems with identification of situations in which hand disinfection is obligatory. For instance, participants did not know that hand disinfection must be performed before contact with the patient $(60 ; 30 \%)$, before putting on gloves $(82 ; 41 \%)$, or after procedures in the patients' surrounding $(74 ; 37 \%)$. The results from the questionnaire and answers for each question are presented in Figure 1, Tables 1 and 2.

\section{Theoretical knowledge and microbiological effectiveness of hand disinfection}

The analysis of microbiological tests demonstrated that bacterial colonisation of HCWs' hands differed significantly between groups depending on their theoretical knowledge of guidelines for hand hygiene. The group that obtained better results in the knowledge test had fewer microorganisms on their hands after hand disinfection, which reflects that knowledge was associated with better microbiological effectiveness of performed procedures $(p=0.004$ Table 3).
Training in hand hygiene - declared participation and its effectiveness

An education program for improvement of hand hygiene is one of the essential components of the WHO multi-modal Hand Hygiene Improvement Strategy. Most of the respondents stated that they took part in a hand hygiene training at least once during the previous year, either theoretical (52\%) or practical training $(55.5 \%)$ (Table 4$)$. In our study about $93 \%$ of HCWs declared the need for training in hand hygiene. We observed that those who declared that they required training in hand hygiene had slightly lower average scores in our questionnaire (20.78 points) than those who did not expect more training in hand hygiene (22.17 points). This observation might reflect the accuracy of self-assessment among HCWs in the scope of the knowledge of hand hygiene recommendations in clinical care. We also aimed to ascertain whether those HCWs who were convinced that they had sufficient knowledge of hand hygiene were aware of the constant need for training. Seventy-five percent of the HCWs who subjectively assessed their knowledge of hand hygiene as sufficient also declared that they still needed training in that field.

The correlation between the declared frequency of participation in educational training and its impact on microbiological effectiveness of performed hand hygiene was examined. More than one theoretical training per year was associated with fewer microorganisms on the hands after hand disinfection $(p=0.02$, Table 5). We also observed that the number of CFUs on hands after hand disinfection was lower if HCWs took part in practical training twice or more per year, although this was statistically insignificant (Table 6).

\section{Discussion}

Several studies have focused on the problem of improper hand hygiene among healthcare workers 
Table 1. Results of knowledge assessment questionnaire for each short question (1-9)

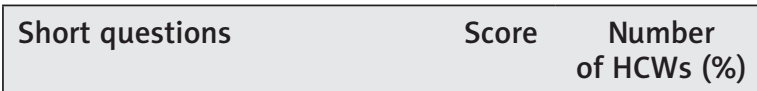

1. Which procedure has better microbicidal activity?

\begin{tabular}{lcc}
\hline a) Hand wash & 0 & $3(1.5 \%)$ \\
\hline $\begin{array}{l}\text { b) Hand wash + hand } \\
\text { disinfection }\end{array}$ & 1 & $134(67 \%)$ \\
\hline c) Hand disinfection & 2 & $63(31.5 \%)$
\end{tabular}

2. Should hands always be washed before contact with a patient?

\begin{tabular}{lcc}
\hline a) Yes & 0 & $118(59 \%)$ \\
\hline b) No & 1 & $82(41 \%)$
\end{tabular}

3. Should hands be disinfected after each contact with a patient?

\begin{tabular}{lcc}
\hline a) Yes & 1 & $189(94.5 \%)$ \\
\hline b) No & 0 & $11(5.5 \%)$
\end{tabular}

4. Which volume of alcohol-based hand disinfectant should be used?

\begin{tabular}{lcc}
\hline a) $1 \mathrm{ml}$ & 0 & $19(9.5 \%)$ \\
\hline b) $5 \mathrm{ml}$ & 1 & $12(6 \%)$ \\
\hline $\begin{array}{l}\text { c) A palmful of the product } \\
\text { in a cupped hand }\end{array}$ & 2 & $169(84.5 \%)$
\end{tabular}

5. Can hand disinfection be replaced by using gloves?
a) Yes
$0 \quad 62(31 \%)$
b) No
$1138(69 \%)$

6. How many steps are included in the procedure of hand disinfection?

\begin{tabular}{lcc}
\hline a) 5 & 0 & $39(19.5 \%)$ \\
\hline b) 6 & 1 & $142(71 \%)$ \\
\hline c) 7 & 0 & $10(5 \%)$ \\
\hline No answer & & $9(4.5 \%)$
\end{tabular}

7. Can solely hand disinfection be performed before medical procedures with patients?
a) Yes

$1138(69 \%)$
b) No
$62(31 \%)$

8. How long should hygienic hand disinfection last?

\begin{tabular}{llc}
\hline a) $15 \mathrm{~s}$ & 0 & $14(7 \%)$ \\
\hline $\begin{array}{l}\text { b) } 20-30 \mathrm{~s} \text { or until hands } \\
\text { are dry }\end{array}$ & 1 & $186(93 \%)$
\end{tabular}

9. Is it correct to change disposable gloves without hand disinfection?

\begin{tabular}{|lcc|}
\hline a) Yes & 0 & $37(18.5 \%)$ \\
\hline b) No & 1 & $163(81.5 \%)$ \\
\hline
\end{tabular}

HCWs - healthcare workers. and healthcare students and have aimed to identify reasons for non-compliance with the guidelines for hand hygiene. However, the number of studies assessing both theoretical knowledge and microbiological effectiveness of hand hygiene is rather limited.

Similarly to our findings, insufficient knowledge of hand hygiene guidelines was underlined as one of the important reasons for improper hand hygiene in hospital settings. According to Nair et al., only $9 \%$ of medical and nursing students had good knowledge regarding hand hygiene, with significantly better knowledge, attitude, and practice among nursing students [9]. Also, our study suggests that theoretical knowledge of hand hygiene is better among nurses, which corresponds with results obtained by van de Mortel, who identified the type of medical profession as a risk-factor for non-compliance with hand hygiene guidelines, and revealed better compliance among nursing students in comparison to medical students [10], as well as Azim's study in which hand hygiene compliance rates were better among nurses [11].

Healthcare workers have problems with identification of situations in which hand hygiene is recommended and necessary, such as the moment before touching a patient, which may suggest a tendency toward self-protection rather than protection of patients $[11,12]$. Our study also indicates that $30 \%$ of HCWs are not aware that they should perform hand disinfection before contact with patients. This corresponds with the rates reported by Kawalec et al. or Wałaszek et al., in which, respectively, about 35\% and 39\% of HCWs did not disinfect their hands in this situation $[13,14]$, or the study by Lytsy et al., in which $18-60 \%$ of medical stuff omitted hand disinfection before touching a patient [7]. According to Garus-Pakowska et al., HCWs obeyed the hand washing procedure before patient contact only in 5.2\% of situations [15].

Another problem is a misconception among one third of HCWs that the use of non-sterile gloves may replace the need for hand disinfection, which was previously highlighted by Scheithauer and Lemmen [16]. Many studies underlined problems with incorrect use of clinical gloves, i.e. improper use for low-risk procedures, failure to change them between procedures, and failure to remove gloves or to perform hand hygiene after their use $[17,18]$. In Poland the overall level of compliance with the guidelines regarding the use of protective gloves is about 50\% [19].

To improve compliance with hand hygiene among medical staff, an educational programme focusing on the WHO guidelines and the "Five Moments" for hand hygiene is needed. Our study showed that more than one theoretical training per year is associated with a lower number of microorganisms on hands after disinfection. The need for training has also been highlighted previously, e.g. by Silva et al., who re- 
Table 2. Results of knowledge assessment questionnaire for each multiple-choice question (10-12)

\begin{tabular}{|c|c|c|c|c|c|}
\hline \multirow{2}{*}{\multicolumn{2}{|c|}{ Multiple-choice questions }} & \multirow{2}{*}{$\begin{array}{l}\text { Maximal } \\
\text { score }\end{array}$} & \multicolumn{2}{|c|}{ Individual results } & \multirow{2}{*}{$\begin{array}{l}\text { Mean } \\
\text { score }\end{array}$} \\
\hline & & & Score & $\begin{array}{l}\text { Number of } \\
\text { HCWs (\%) }\end{array}$ & \\
\hline \multirow[t]{9}{*}{10.} & When should hand washing be performed? & \multirow{9}{*}{6} & & & \multirow{9}{*}{3.85} \\
\hline & a) When hands are visibly dirty & & $6 / 6$ & $66(33 \%)$ & \\
\hline & b) Always before hand disinfection & & $5 / 6$ & $29(14.5 \%)$ & \\
\hline & c) Always before eating & & $4 / 6$ & $18(9 \%)$ & \\
\hline & d) Before assisting a patient with eating & & \multirow{2}{*}{$3 / 6$} & \multirow{2}{*}{$35(17.5 \%)$} & \\
\hline & e) After using the toilet & & & & \\
\hline & f) Before starting work and after longer breaks & & $2 / 6$ & $19(9.5 \%)$ & \\
\hline & $\begin{array}{l}\text { g) Always after contact with a patient colonised with } \\
\text { Clostridium difficile }\end{array}$ & & $1 / 6$ & $15(7.5 \%)$ & \\
\hline & h) Always after contact with an HIV-positive patient & & $0 / 6$ & $18(9 \%)$ & \\
\hline \multirow[t]{6}{*}{11.} & Should hands be washed before disinfection? & \multirow{6}{*}{3} & & & \multirow{6}{*}{1.015} \\
\hline & a) Yes, always & & $3 / 3$ & $0(0 \%)$ & \\
\hline & b) Yes, after contact with an HIV-positive patient & & $2 / 3$ & $68(34 \%)$ & \\
\hline & $\begin{array}{l}\text { c) Yes, after contact with patient/surroundings of a patient with } \\
\text { diarrhoea caused by Clostridium difficile }\end{array}$ & & $1 / 3$ & $67(33.5 \%)$ & \\
\hline & d) Yes, if hands are visibly dirty & & \multirow{2}{*}{$0 / 3$} & \multirow{2}{*}{$65(32.5 \%)$} & \\
\hline & e) No & & & & \\
\hline \multirow[t]{11}{*}{12.} & When should hygienic hand disinfection be performed? & & & & \multirow{11}{*}{6.8} \\
\hline & a) Before touching the patient & 9 & $9 / 9$ & $74(37 \%)$ & \\
\hline & b) After touching the patient & 9 & $8 / 9$ & $32(16 \%)$ & \\
\hline & $\begin{array}{l}\text { c) After contact with body fluids or excretions, mucous } \\
\text { membranes }\end{array}$ & 9 & $7 / 9$ & $25(12.5 \%)$ & \\
\hline & d) Before performing clean or aseptic tasks & 9 & $6 / 9$ & $17(8.5 \%)$ & \\
\hline & e) After performing medical procedures & 9 & $5 / 9$ & $16(8 \%)$ & \\
\hline & f) Before using non-sterile gloves & 9 & $4 / 9$ & $10(5 \%)$ & \\
\hline & g) After removal of sterile or non-sterile gloves & 9 & $3 / 9$ & $3(1.5 \%)$ & \\
\hline & $\begin{array}{l}\text { h) If moving from a contaminated body site to another body site } \\
\text { during care of the same patient }\end{array}$ & 9 & $2 / 9$ & $11(5.5 \%)$ & \\
\hline & \multirow[t]{2}{*}{ i) After touching the patient's immediate environment } & 9 & $1 / 9$ & $10(5 \%)$ & \\
\hline & & 9 & $0 / 9$ & $2(1 \%)$ & \\
\hline
\end{tabular}

HCWs - healthcare workers.

Table 3. Number of CFUs on hands before and after hand disinfection according to theoretical knowledge of hand hygiene procedures

\begin{tabular}{|lccc|}
\hline Hand disinfection & \multicolumn{2}{c|}{ Theoretical knowledge of hand hygiene } & $P$-value \\
\cline { 2 - 3 } Before & $\leq 75 \%$ correct answers & $>75 \%$ correct answers & \\
After & $\begin{array}{c}447.30 \mathrm{CFU} / 100 \mathrm{~cm}^{2} \\
( \pm 455.71)\end{array}$ & $\begin{array}{c}327.53 \mathrm{CFU} / 100 \mathrm{~cm}^{2} \\
( \pm 405.78)\end{array}$ & 0.05 \\
& $\begin{array}{c}274.60 \mathrm{CFU} / 100 \mathrm{~cm}^{2} \\
( \pm 527.41)\end{array}$ & $\begin{array}{c}106.91 \mathrm{CFU} / 100 \mathrm{~cm}^{2} \\
( \pm 237.46)\end{array}$ & 0.004 \\
\hline
\end{tabular}

CFU-colony-forming unit. 
Table 4. Declared frequency of participation in hand hygiene training

\begin{tabular}{|lcccc|}
\hline Declared frequency & \multicolumn{2}{c|}{ Theoretical training } & \multicolumn{2}{c|}{ Practical training } \\
\cline { 2 - 5 } Once a year & Number of HCWs & $\%$ & Number of HCWs & $\%$ \\
Twice a year & 104 & 52 & 111 & 55.5 \\
3 or more times a year & 55 & 27.5 & 50 & 25 \\
No answer & 23 & 11.5 & 20 & 10 \\
Total & 18 & 9 & 19 & 9.5 \\
\hline
\end{tabular}

HCWs - healthcare workers.

Table 5. Number of CFUs on hands after hand disinfection according to frequency of theoretical training in hand hygiene

\begin{tabular}{|lcccc|}
\hline & \multicolumn{2}{c}{ Frequency of theoretical training in hand hygiene } & $P$-value \\
\cline { 2 - 4 } & 1 per year & 2 per year & 3 or more per year & \\
$\begin{array}{l}\text { Mean number of CFUs on } \\
\text { hands after hand disinfection }\end{array}$ & $\begin{array}{c}274.62 \mathrm{CFU} / 100 \mathrm{~cm}^{2} \\
( \pm 506.95)\end{array}$ & $\begin{array}{c}102.47 \mathrm{CFU} / 100 \mathrm{~cm}^{2} \\
( \pm 243.17)\end{array}$ & $\begin{array}{c}101.22 \mathrm{CFU} / 100 \mathrm{~cm}^{2} \\
( \pm 331.24)\end{array}$ & 0.02 \\
\hline
\end{tabular}

CFU - colony-forming unit.

Table 6. Number of CFUs on hands after hand disinfection according to frequency of practical training in hand hygiene

\begin{tabular}{|lcccc|}
\hline & \multicolumn{2}{c}{ Frequency of practical training in hand hygiene } & \multirow{2}{*}{$P$-value } \\
\cline { 2 - 4 } & 1 per year & 2 per year & 3 or more per year & \\
Mean number of CFUs on & $242.02 \mathrm{CFU} / 100 \mathrm{~cm}^{2}$ & $108.40 \mathrm{CFU} / 100 \mathrm{~cm}^{2}$ & $126.60 \mathrm{CFU} / 100 \mathrm{~cm}^{2}$ & 0.13 \\
hands after hand disinfection & $( \pm 476.89)$ & $( \pm 262.78)$ & $( \pm 352.13)$ & \\
\hline
\end{tabular}

CFU - colony-forming unit.

ported that $34 \%$ of HCWs did not attended specific training on hand hygiene [20]. Similarly, a study conducted among Polish medical students by Różańska et al. reported that the professional practice of $22.9 \%$ of students was not preceded by any training in the field of hospital hygiene and in $28 \%$ of cases training did not cover hand hygiene [21]. According to Jarosik and Garus-Pakowska's findings, HCWs are aware of the need for constant education and obligatory training, and these actions are most frequently indicated as possible factors for improvement of hand hygiene [22]. Sadeghi-Moghaddam et al. reported that educational intervention improved hand hygiene compliance from $30 \%$ to $70 \%$ [23]. Also, Niecwietajewa et al. revealed that personalised and group training combined with microbiological hand hygiene control among HCWs resulted in higher consumption of alcohol-based hand disinfectant in hospital wards [24], while Stock et al. observed that hands-on training conducted in small groups with a wide array of interactive teaching methods significantly improved hand hygiene compliance among nurses [25]. Nonetheless, more studies are needed to optimise strategies for better compliance with guidelines and monitoring of hand hygiene, to determine which additional promotional activities can augment improvements in hand hygiene and its quality, and to establish the most effective methods of providing feedback [26]. Recent studies suggest that simplifying the procedure of hand hygiene by reducing the number of recommended six-steps to three, providing the same level of microbiological effectiveness, might be a possible way to improve adherence to hand hygiene actions [27].

To summarise, for better compliance with hand hygiene among HCWs, there is still a need to design a multi-modal and combined strategy, which should focus not only on theoretical knowledge and the need for training but also on many other aspects in clinical settings.

\section{Conclusions}

The HCWs are not aware of the situations in which they should perform hand disinfection. Theoretical knowledge of guidelines for hand hygiene is related with fewer microorganisms on the hands after hand disinfection. Educational training is an important element increasing the efficacy of performed hand hygiene procedures. More than one theoretical training per year was associated with better hand disinfection efficiency. There is a need to design and implement 
multi-modal educational strategies to improve hand hygiene among HCWs.

\section{Conflict of interest}

The authors declare no conflict of interest.

\section{References}

1. World Health Organization: WHO guidelines on hand hygiene in health care. Geneva, 2009.

2. Allegranzi B, Pittet D. Role of hand hygiene in healthcare-associated infection prevention. J Hosp Infect 2009; 73: 305-315.

3. Protano C, Cammalleri V, Romano VS, Valeriani F, Vitali M. Hospital environment as a reservoir for cross transmission: cleaning and disinfection procedures. Ann Ig 2019; 31: 436-448.

4. Novoa AM, Pi-Sunyer T, Sala M, Molins E, Castells X. Evaluation of hand hygiene adherence in a tertiary hospital. Am J Infect Control 2007; 35: 676-683.

5. Randle J, Arthur A, Vaughan N. Twenty-four-hour observational study of hospital hand hygiene compliance. J Hosp Infect 2010; 76: 252-255.

6. Le C D, Lehman EB, Nguyen TH, Craig TJ. Hand hygiene compliance study at a large Central Hospital in Vietnam. Int J Environ Res Public Health 2019; 16: 607.

7. Lytsy B, Melbarde-Kelmere A, Hambraeus A, Liubimova A, Aspevall O. A joint, multilateral approach to improve compliance with hand hygiene in 4 countries within the Baltic region using the World Health Organization's SAVE LIVES: Clean Your Hands model. Am J Infect Control 2016; 44: 1208-1213.

8. Garus-Pakowska A. Wpływ obciążenia praca na przestrzeganie procedur higienicznych przez personel medyczny. Med Pr 2011; 62: 369-376.

9. Nair SS, Hanumantappa R, Hiremath SG, Siraj MA, Raghunath P. Knowledge, attitude, and practice of hand hygiene among medical and nursing students at a tertiary health care centre in Raichur, India. ISRN Prev Med 2014; 2014: 608927.

10. Van de Mortel TF, Kermode S, Progano T, Sansoni J. A comparison of the hand hygiene knowledge, beliefs and practices of Italian nursing and medical students. J Adv Nurs 2012; 68: 569-579.

11. Azim S, McLaws ML. Doctor, do you have a moment? National Hand Hygiene Initiative compliance in Australian hospitals. Med J Aust 2014; 200: 534-537.

12. Jansson MM, Syrjälä HP, Ohtonen PP, Meriläinen $\mathrm{MH}$, Kyngäs HA, Ala-Kokko TI. Simulation education as a single intervention does not improve hand hygiene practices: a randomized controlled follow-up study. Am J Infect Control 2016; 44: 625-630.

13. Kawalec A, Kawalec A, Pawlas KP. Przestrzeganie procedur higienicznych przez studentów wydziału lekarskiego. Med Pr 2014; 65: 593-599.

14. Wałaszek M, Kołpa M, Wolak Z, Różańska A, Wójkowska-Mach J. Poor hand hygiene procedure compliance among Polish medical students and physicians - the result of an ineffective education basis or the impact of organizational culture? Int J Environ Res Public Health 2017; 14: pi: E1026.

15. Garus-Pakowska A, Sobala W, Szatko F. Observance of hand washing procedures performed by the medical personnel before patient contact. Part I. Int J Occup Med 2013; 26: 113-121.

16. Scheithauer S, Lemmen SW. How can compliance with hand hygiene be improved in specialized areas of a university hospital? J Hosp Infect 2013; 83: 17-22.

17. Loveday HP, Lynam S, Singleton J, Wilson J. Clinical glove use: healthcare workers' actions and perceptions. J Hosp Infect 2014; 86: 110-116.

18. Kampf G, Lemmen S. Disinfection of gloved hands for multiple activities with indicated glove use on the same patient. J Hosp Infect 2017; 97: 3-10.

19. Garus-Pakowska A, Sobala W, Szatko F. The use of protective gloves by medical personnel. Int J Occup Med 2013; 26: 423-429.

20. Silva D, Andrade O, Silva E. Perspective of health professionals on hand hygiene. Aten Primaria 2014; 46: 135139.

21. Różańska A, Wójkowska-Mach J, Bulanda M. Praktyka zawodowa i staż pracy w ochronie zdrowia a wiedza studentów kierunków medycznych o wybranych procedurach higieny rąk. Med Pr 2016; 67: 623-633.

22. Jarosik M, Garus-Pakowska A. Wiedza i przestrzeganie procedur higienicznych jako element profilaktyki przeciwzakaźnej w pracy pielęgniarek. Hygeia Public Health 2012; 47: 215-222.

23. Sadeghi-Moghaddam P, Arjmandnia M, Shokrollahi M, Aghaali M. Does training improve compliance with hand hygiene and decrease infections in the neonatal intensive care unit? A prospective study. J Neonatal Perinatal Med 2015; 8: 221-225.

24. Niecwietajewa I, Pracz W, Giemza M, Jakubiak J, Szymańczak M, Marusza W. Mikrobiologiczna kontrola higieny rąk jako ważny element multimodalnej strategii prewencji zakażeń związanych z opieka zdrowotną. Zakażenia XXI wieku 2018; 1: 209-215.

25. Stock S, Tebest R, Westermann K, Samel C, Strohbücker B, Stosch C, Wenchel HM, Redaèlli M. Implementation of an innovative hands-on training to improve adherence to hygiene rules: a feasibility study. Nurse Educ Today 2016; 36: 407-411.

26. Boyce JM. Current issues in hand hygiene. Am J Infect Control 2019; 47: A46-A52.

27. Tschudin-Sutter S, Rotter ML, Frei R, Nogarth D, Häusermann P, Stranden A, Widmer AF. Simplifying the WHO 'how to hand rub' technique: three steps are as effective as six - results from an experimental randomized crossover trial. Clin Microbiol Infection 2017; 23: 409e1-409e4.

\section{Address for correspondence:}

\section{Anna Maria Kawalec MD}

Department of Hygiene

Wroclaw Medical University

ul. J. Mikulicza-Radeckiego 7

50-345 Wroclaw, Poland

E-mail: anna.kawalec@student.umed.wroc.pl 